\title{
СПЕЦИФІКА ЗАСТОСУВАННЯ КОГНІТИВНИХ ТЕХНОЛОГІЙ ТА ШТУЧНОГО ІНТЕЛЕКТУ В СУЧАСНІЙ БАНКІВСЬКІЙ ДІЯЛЬНОСТІ
}

\author{
Волинський національний університет імені Лесі Украӥнки
}

\begin{abstract}
Інтенсивний технологічний розвиток суспільства справляє суттєвий вплив не лише на зміну структури виробничих відносин, але й істотно впливає на трансформацію фінансової i, зокрема, банківської системи. При цьому внаслідок ускладнення мережевих технологій, які вже давно використовуються для забезпечення функціонування онлайн-банкінгу, виникають можливості переведення усього комплексу обслуговування клієнтів банку у сферу дистанційного обслуговування. Інновації, пов'язані з використанням когнітивних технологій та штучного інтелекту, дають змогу трансформації традиційних автоматизованих систем дистанційного банківського обслуговування клієнтів в новий технологічний та інформаційний вимір, наслідком чого є формування цифрового банкінгу. При цьому, поточні тенденції свідчать, що переорієнтація банківських послуг в цифрові технології відбувається достатньо швидкими темпами, наслідком чого є скорочення мереж банківських відділень обслуговування клієнтів відбувається онлайн та за допомогою спеціалізованих терміналів, кожен з яких за своїм функціоналом здатен замінити до десяти працівників.

В статті розглянуто сучасну специфіку формування нової системи банківського обслуговування, котре пов'язане із застосуванням когнітивних технологій та штучного інтелекту і має своїм наслідком формування нових принципів взаємодії та трансформації систем «клієнт - банк» в цифровий банкінг. Визначено, що впровадження таких технологій у банківську діяльність дозволяє банкам суттєво економити на утриманні окремих відділень та скорочувати чисельність персоналу, задіяного в обслуговування клієнтів. Досліджено, що перехід до цифрового банкінгу значно збільшує потребу в забезпеченні інформаційної безпеки клієнтів банку, оскільки більшість їхніх операцій 3 рахунками відбувається через мережу і є потенційно вразливими до недоброчесних дій. Відтак, можна зробити висновок, що інтенсивне впровадження цифрових технологій в банківську діяльність $є$ неможливим без забезпечення належної системи інформаційної безпеки з боку банківських установ.
\end{abstract}

Ключові слова: банківські інновації, когнітивні технологї, итучний інтелект, цчифровий банкінг, банківська безпека.

\section{SPECIFICS OF APPLICATION OF COGNITIVE TECHNOLOGIES AND ARTIFICIAL INTELLIGENCE IN MODERN BANKING ACTIVITY}

\author{
Lesya Ukrainka Volyn National University
}

Intensive technological development of society has a significant impact not only on changing the structure of industrial relations, but also significantly affects the transformation of the financial and, in particular, the banking system. At the same time, due to the complexity of network technologies, which have long been used to ensure the functioning of online banking, there are opportunities to transfer the entire complex of customer service to the bank in the field of remote service. Innovations related to the use of cognitive technologies and artificial intelligence allow the transformation of traditional automated remote banking systems into a new technological and information dimension, resulting in the formation of digital banking. At the same time, current trends show that the reorientation of banking services to digital technology is quite fast, resulting in a reduction of bank branch networks - customer service is online and through specialized terminals, each of which can replace up to ten employees.

The article considers the modern specifics of the formation of a new banking system, which is associated with the use of cognitive technologies and artificial intelligence and results in the formation of new principles of interaction and transformation of "client - bank" systems into digital banking. It is determined that the introduction of such technologies in banking allows banks to significantly save on the maintenance of individual branches and reduce the number of staff involved in customer service. It has been studied that the transition to digital banking 
significantly increases the need for information security of the bank's customers, as most of their account transactions take place through the network and are potentially vulnerable to dishonesty. Therefore, it can be concluded that the intensive introduction of digital technologies in banking is impossible without ensuring a proper information security system by banking institutions. security.

Keywords: banking innovations, cognitive technologies, artificial intelligence, digital banking, banking

Постановка проблеми у загальному вигляді та ії зв'язок 3 важливими науковими та практичними завданнями. Як відомо, формування сучасних систем онлайн-банкінгу базувалося на перших автоматичних програмних застосунках «клієнтбанк» і фактично є істотно вдосконаленим їх елементом. Якщо перші автоматичні застосунки потребували встановлення спеціалізованого програмного забезпечення за допомогою працівників банку, а швидкість проведення операцій не надто відрізнялася від їх реалізації в самій банківській установі, то до початку 2010-х років відбулося значне технічне та технологічне вдосконалення таких систем. Наразі можна вести мову про повноцінний онлайн-банкінг, який широко застосовується у процесі взаємодії 3 клієнтами банку за допомогою мережі Інтернет. При цьому проведення багатьох банківських операцій не потребує залучення працівників банку, а клієнти можуть взаємодіяти з своїми рахунками в режимі онлайн через спеціалізовані веб-застосунки.

Разом 3 тим, технічні принципи реалізації банківських операції залишаються незмінними, адже хоча взаємодія з клієнтами відбувається через інтернет, безпосередній рух коштів проводиться через захищені і відокремлені банківські платіжні мережі. Відтак не можна вести мову про повну автономність клієнта, що працює з онлайнбанкінгом. Разом 3 тим, інноваційні рішення, що поширюються останнім часом i базуються на когнітивних технологіях взаємодії, дозволяють значно розширити як можливості банків щодо задоволення потреб клієнтів та збільшення швидкості їх обслуговування, так і забезпечують недоступні раніше рішення щодо ефективного превентивного виявлення потреб клієнтів та задоволення їх на основі оперативного аналізу. Провідне місце в таких технологічних інноваціях займає штучний інтелект, застосування якого дозволяє не лише підвищити і пришвидшити процес обслуговування клієнтів і прийняття найбільш оптимальних рішень щодо управляння їх рахунками або навіть ресурсами самого банку, але й загалом призводить да суттєвого підвищення ефективності таких рішень i, як наслідок - збільшення прибутковості банківської установи загалом.

Таким чином, можна вести мову про формування під впливом інноваційних змін нової форми мережевої онлайн взаємодії у сфері банківської діяльності, яка характеризується як цифровий банкінг, особливості та принципи функціонування якого потребують досконалого вивчення.

Аналіз останніх досліджень і публікацій, у яких започатковано вирішення даної проблеми. Дослідженням проблем підвищення ефективності банківської діяльності в аспекті функціонування систем онлайн-банкінгу, а також впровадження в банківську діяльність новітніх інноваційних систем пов'язаних 3 цифровими технологіями присвячено чимало праць. 3 них варто виділити роботи таких дослідників, як Ю. І. Грудзевич [1], М. І. Карлін [2], В. О. Корнівська [3], Т. В. Котуранова [4], Л. В. Мороз [5], Р. І. Содома [6], О. В. Стащук [7], Т. О. Шматковська [8] та інші. Однак, стрімкі технологічні зміни, які відбуваються в банківській діяльності та швидке поширення інноваційних цифрових технологій в банківській діяльності, потребують проведення комплексу досліджень специфіки формування нових специфічних систем онлайн-банкінгу, які трансформуються в систему цифрового банкінгу.

Цілі статті. Метою статті $є$ дослідження специфіки формування систем цифрового банкінгу в процесі впровадження в банківську діяльність цифрових технологічних рішень, що базуються на застосування когнітивних технологій та штучного інтелекту. 
Виклад основного матеріалу дослідження 3 повним обгрунтуванням отриманих наукових результатів. Трансформація систем онлайн-банкінгу в сучасний інтернет-банкінг, котра відбувалася протягом останніх десяти років, мала на меті спростити взаємодію з банками для їх клієнтів, а також - пришвидшити загальну тривалість банківських операцій, котрі були доступними для клієнтів через банківські інтернет-портали. Проте, оскільки реалізація цих завдань передбачала широке впровадження новітніх інноваційних рішень у сфері інтернет-комунікацій, то логічним наслідком стало розширення можливостей підключення до інтернет-банкінгу не лише 3 стаціонарних комп'ютерів, але й за допомогою ряду мобільних пристроїв (смартфонів, планшетів, смарт-годинників тощо). Відповідно, для обслуговування таких комунікацій банки були змушені широко запроваджувати у свій інтернет-банкінг програмні рішення, що базувалися на новітніх системах мобільної взаємодії, котрі базувалися на когнітивних технологіях. Відтак, наразі обслуговування клієнтів інтернет-банкінгу відбувається більшою мірою за допомогою чат-ботів, а не банківських кол-центрів.

Основними перевагами когнітивних технологій, які застосовуються у банківській діяльності на даний момент можна виділити наступні:

- когнітивні технології дають змогу банкам в режимі онлайн виявляти в структурі здійснюваних банківських операцій найбільш ризиковані або проблемні 3 них i оперативно вносити корективи в процес управління фінансовими потоками банківської установи;

- підвищується ефективність організації взаємодії банку 3 його клієнтами, незалежно від місця їх знаходження, а також покращується і пришвидшується взаємодія структурних підрозділів банку між собою;

- виникають можливості цілодобового контролю за ефективним використанням ресурсів банку з оперативним перенаправленням їх на здійснення найбільш прибуткових на даний час операцій;

- виникають можливості постійного аналізу даних, що надходять із зовнішнього середовища 3 одержанням результатів, що характеризуються надзвичайно високою точністю опрацювання, що дає змогу банкам приймати більш виважені стратегічні рішення в процесі управління, а також це дозволяє банківським установам випереджаючими темпами визначати потреби клієнтів і вчасно пропонувати їм необхідні рішення щодо обслуговування їх потреб у фінансовій сфері;

- підвищується загальна ефективність управління банком у зв'язку з можливістю опрацювання великих масивів даних, що надходять до банку цілодобово в режимі онлайн і потрапляють в систему автоматичного опрацювання.

Ще одним надзвичайно важливим наслідком широкого впровадження когнітивних технологій в банківську діяльність є скорочення чисельності персоналу банківських установ, а також зменшення числа банківських відділень (або ж перевід існуючих на безособове обслуговування за допомогою терміналів). Наслідком таких тенденцій $є$ відчутне скорочення витрат банку на персонал та на утримання структурних підрозділів. Головне - що клієнти банку при цьому не відчувають жодних незручностей, оскільки існуючі цифрові рішення цілком дозволяють їм обходитися існуючими програмними рішеннями та додатками.

Таким чином, можна вести мову про загальне зниження вартості банківських продуктів, що дозволяє розширити межі їх застосування та залучити нових клієнтів до користування банківськими послугами, які були їм недоступні раніше. Проте такий підхід передбачає також необхідність формування в системі банківського менеджменту відділів, котрі орієнтуються на управління цифровими відносинами в системі інтернетбанкінгу. Якщо ж додати до цього усі наведені вище можливості когнітивних технологій, які одержують банки, то можна вести мову про формування стратегії управління цифровими відносинами банківської установи (рис. 1). 


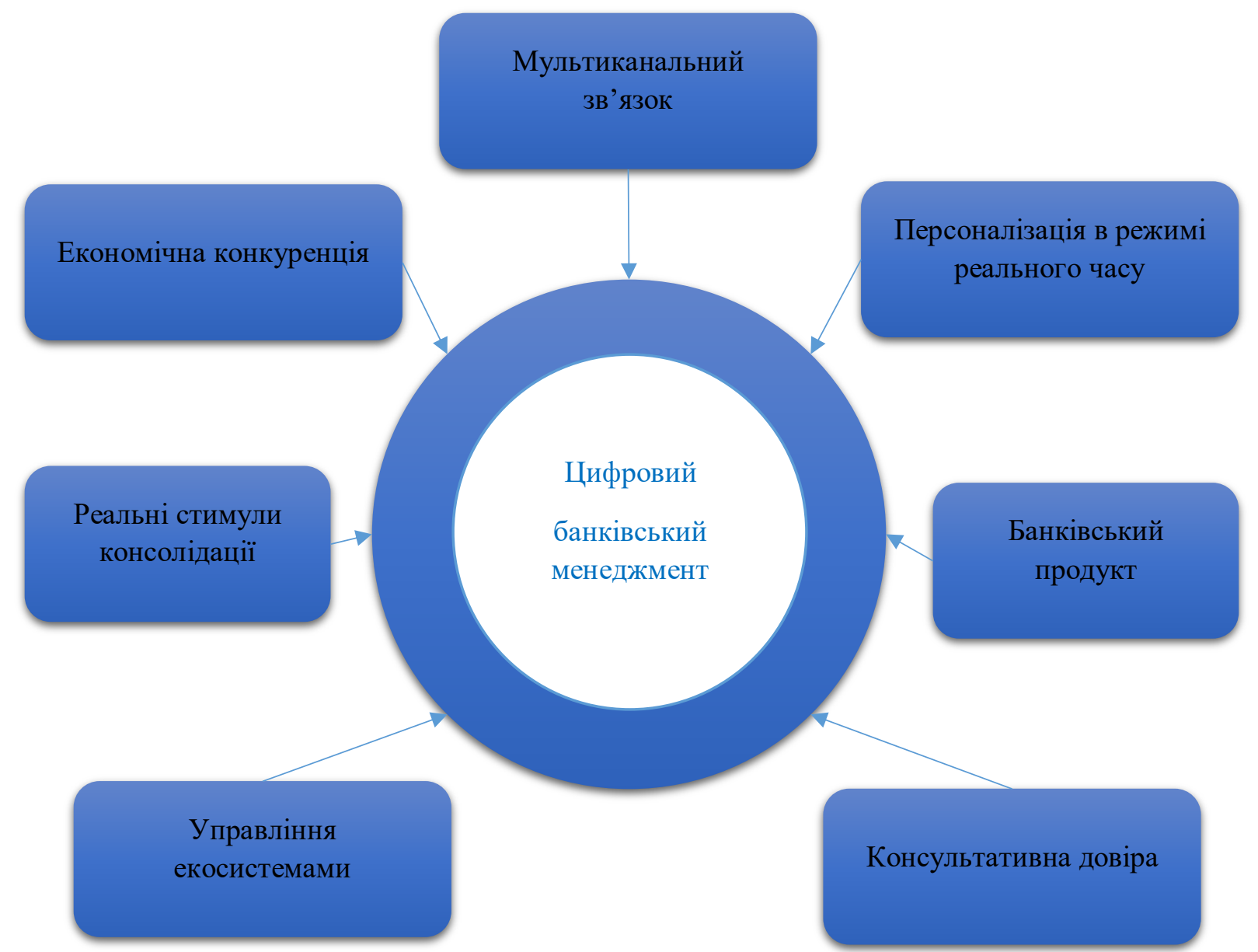
установи

Рис. 1. Формування стратегії управління цифровими відносинами банківської Джерело: [9]

Таким чином, можна зробити висновок, що колишні підходи ефективного управління банком, коли визначальною була орієнтація на банківський продукт та кого параметри, в умовах цифрового банкінгу більше не будуть забезпечувати успіх банківської установи на ринку. Натомість створення та реалізація справжньої стратегії управління цифровими відносинами визначатиме рівень складності ціноутворення банківських продуктів, що є складним, але необхідним процесом для більшості банків.

Крім того, окремо необхідно визначити на необхідності застосування штучного інтелекту в процесі формування цифрового банкінгу. Причиною цього $є$ те, що штучний інтелект, застосовуваний в формуванні банківських продуктів, забезпечує для банківської установи зростання ефективності трансформації онлайн-банкінгу в цифровий банкінг. До основних передумов забезпечення зростання такої ефективності можна віднести наступні:

- інтенсивна діджиталізація банківських продуктів має наслідком зростання масиву даних, які підлягають постійному та безперервному аналізу. При цьому залучення фахівців-аналітиків $є$ екстенсивним шляхом, а застосування програмних рішень на основі штучного інтелекту дозволяють забезпечити швидку та ефективну обробку даних й реалізацію їх в готових цифрових продуктах банку;

- швидкий технологічний розвиток дає можливість все більшій кількості клієнтів банку використовувати більш складні банківські продукти за рахунок постійного зростання цифрових потужностей використовуваних гаджетів та пристроїв, які з часом стають дешевшими і доступнішими ще більшій кількості споживачів; 
- інтенсивні дослідження у сфері програмних рішень дозволяються вдосконалювати існуючі та застосовувати абсолютно нові алгоритми аналізу та використання великих масивів даних, обробка яких за допомогою штучного інтелекту стає базою для прийняття більш ефективних рішень у сфері формування цифрових банківських продуктів.

Висновки. Отже, можна стверджувати, що нові технологічні умови та інноваційні рішення у сфері діджиталізації створюють умови для переходу комерційних банків до нового типу функціонування - цифрового банкінгу, який поєднує в собі навички, технології та можливості для трансформації основних банківських систем таким чином, щоб клієнти ставили на перше місце та дозволяли банкам ефективно реалізовувати цифрові банківські продукти у своїх операціях. При цьому обмеження застарілих IT-систем наразі продовжують заважати багатьом банківським установам покращувати свій досвід роботи 3 клієнтами. Тому лише формування ефективної стратегії управління цифровими відносинами в банку, орієнтованої на широке впровадження інновацій у банківську діяльність, можуть забезпечити банківським установам модернізацію їх застарілих IT-систем та вдосконалити програми цифрових послуг, формуючи таким чином систему цифрового банкінгу.

\section{Список бібліографічного описv:}

1. Грvдзевич Ю. І.. Шматковська Т. О.. Борисюк О. В. Запровадження коефіцієнту NSFR в практику функціонування комерційних банківських структур. Вісник ЛНАУ. 2020. №27. С. 99-103.

2. Карлін М. І.. Шматковська Т. О.. Борисюк О. В. Банківські інновації в умовах формування цифрової економіки. Економіка та суспільство. 2021. №27.

3. Корнівська В. О. Цифровий банкінг: ризики фінансової дигіталізації. Проблеми економіки. 2017. №3. С. $254-261$.

4. Котуранова Т. В., Вартоха Я. С., Александрова М. О. Інтернет-банкінг в Україні -інноваційний розвиток банківської сфери. Економічний простір. 2019. №146. С. 43-56.

5. Мороз, Л. В. Перспективи розвитку онлайн-банкінгу в Україні. Науковий вісник НЛТУ Украӥни. 2012. №13 (22). С. $218-225$.

6. Содома Р. І., Агрес О. Г., Шматковська Т. О. Платіжні системи в умовах діджиталізації. Вісник ЛНАУ. 2020. №27. C 75-82.

7. Сташvк О. В.. Боирсюк О. В.. Шматковська Т. О. Роль банківських інновашій на фінансовомv ринку в vмовах глобального фінансового простору. Економічний часопис Волинського національного університету ім. Лесі Украӥнки. 2020. №4 (24). C. 71-79.

8. Шматковська Т. О.. Содома Р. І., Марків Г. В., Східницька Г. В. Інноваційний проєкт з електронного банкінгу. Вісник ЛНАУ. 2019. С. 85-91.

9. McIntyre, A. How well does your bank's pricing strategy fit the digital economy? Accenture. URL: https://bankingblog.accenture.com/how-well-does-your-banks-pricing-strategy-fit-digital-economy (дата звернення 01.08.2021).

\section{Reference:}

1. Grudzevych, Yu. I., Shmatkovska, T. O., Borysiuk, O. V. Zaprovadzhennia koeficientu NSFR v praktyku funktsionuvannia komertsiinykh bankivskykh struktur [Introduction of the NSFR ratio in the practice of commercial banking structures]. Visnyk LNAU - Bulletin of LNAU. 2020. Vol. 27. Pp. 99-103 [in Ukrainian].

2. Karlin. M. I.. Shmatkovska. T. O.. Borvsiuk. O. V. Bankivski innovatsii v umovakh formuvannia tsvfrovoi ekonomikv [Banking innovations in the formation of the digital economy]. Ekonomika ta suspilstvo - Economy and society. 2021. Vol. 27. 3. Kornivska. V. O. Tsyfrovyi banking: ryzyky finansivoi digitalizatsii [Digital banking: risks of financial digitalization]. Problemy ekonomiky - Problems of the economy. 2017. Vol. 3. Pp. 254-261 [in Ukrainian].

4. Koturanova, T. V., Vartokha, Ya. S., Aleksandrova, M. O. Internet banking v Ukraini - innovatsiinyi rozvytok bankivskoi sfery [Internet banking in Ukraine - innovative development of the banking sector]. Ekonomichnyi prostir - Economic space. 2019. Vol. 146. Pp. 43-56 [in Ukrainian].

5. Moroz, L. V. Perspektyvy rozvytku onlain-bankingu v Ukraini [Prospects for the development of online banking in Ukraine]. Naukovyi visnyk NLTU Ukrainy - Scientific Bulletin of NUFU of Ukraine. 2012. Vol. 13 (22). Pp. 218-225 [in Ukrainian]. 6. Sodoma R. I., Ahres, O. G., Shmatkovska, T. O. Platizhni systemy v umovakh didzhytalizatsii [Payment systems in the conditions of digitalizationl. Visnyk LNAU - Bulletin of LNAU. 2020. Vol. 27. Pp. 75-82 Гin Ukrainianl.

7. Stashchuk. O. V.. Borvsiuk. O. V.. Shmatkovska. T. O. Rol bankivskvkh innovatsii na finansovomu rvnku v umovakh globalnogo finansovogo prostoru ГThe role of banking innovations in the financial market in the global financial sbacel.Ekonomichnvi chasopvs Volvnskogo Natsionalnogo universytetu im. Lesi Ukrainky - Economic journal of Lesya Ukrainka Volyn National University. 2020. Vol. 4(24). Pp. 71-79 [in Ukrainian].

8. Shmatkovska, T. O., Sodoma R. I., Markiv, G. V., Skhidnytska, G. V. Innovatsiinyi proekt z elektronnogo bankingu [Innovative project on electronic banking]. Visnyk LNAU - Bulletin of LNAU. 2019. Pp. 85-91 [in Ukrainian].

9. McIntyre, A. How well does your bank's pricing strategy fit the digital economy? Accenture. Retrieved from: https://bankingblog.accenture.com/how-well-does-your-banks-pricing-strategy-fit-digital-economy (Accessed on 01.08.2021).

Дата подання публікації 10.08.2021p. 